\title{
SAFETY PROFILE OF COVID-19 VACCINES IN PREGNANT AND POSTPARTUM WOMEN IN BRAZIL
}

2 Authors names: Yaping Qiao PhD* ${ }^{1}$, Ariane de Jesus Lopes de Abreu MSc*2, Carolina Zampirolli Dias

$3 \mathrm{MSc}^{2}$, Xing Meng $\mathrm{PhD}^{1}$, Rafaela Vansan Ferreira $\mathrm{BSc}^{2}$, Ramon Gonçalves Pereira $\mathrm{MSc}^{2}$, Guilherme Silva

4 Julian $\mathrm{MSC}^{2}$, Weidong Yin MBA ${ }^{1}$

$5 \quad *$ Y.P.Q. and A.J.L.A contributed equally to this article.

6 Affiliations and full addresses:

$7 \quad{ }^{1}$ Sinovac Biotech Co, Ltd, Beijing, P.R. China; qiaoyp6109@sinovac.com (Y.P.Q.); mengx@sinovac.com

8 (X.M.); yinwd@sinovac.com (W.D.Y.)

9 ²IQVIA Brazil, São Paulo 04719-002, SP, Brazil; ariane.dejesuslopesdeabreu@iqvia.com (A.J.L.A.);

10 carolina.zampirolli@iqvia.com (C.Z.D.); rafaela.ferreira@iqvia.com (R.V.F.); rpereira2@br.imshealth.com

11 (R.G.P.); guilherme.julian@iqvia.com (G.S.J.)

Corresponding Author:

Weidong Yin

Sinovac Biotech Co, Ltd, No. 39, Shangdi Xi Road, Haidian District, Beijing 100085, Beijing, P.R. China, yinwd@sinovac.com

\section{Abstract}

Background: Although COVID-19 vaccines are currently under use in pregnant and postpartum women, there is still lack of evidence regarding safety and effectiveness in these populations. This study aims to describe the safety profile of COVID-19 vaccines in pregnant and postpartum women in the early stage of vaccination campaign in Brazil. Methods: This is an observational cross-sectional study using data from the Brazilian surveillance information system for adverse events (SI-EAPV) to characterize the safety of COVID-19 vaccines available (Sinovac/Butantan, Pfizer/BioNTech, AstraZeneca and Janssen) in Brazilian pregnant and postpartum women after receiving it from April to August 2021. A descriptive analysis was performed to assess the frequency and incidence rate of the adverse events (AE) for COVID-19 vaccines. Results: A total of 3,333 adverse events following COVID-19 immunization were reported for the study population in the SIEAPV. The incidence of AE found was $309.4 / 100,000$ doses (95\% Cl 297.23, 321.51). Regarding the four vaccines available in the country, Sinovac/Butantan had the lowest incidence $(74.08 / 100,000$ doses; $95 \% \mathrm{Cl} 63.47,84.69)$. Systemic events were the most frequent notified for the group (82.07\%), followed by local (11.93\%) and maternal (4.74\%), being most of them classified as non-severe (90.65\%). Conclusion: A similar pattern of AE as stated in other studies was found, with even better results for non-viral vector vaccines, corroborating to the recommendation of vaccination for these groups. Even though, further studies appraising a longer observation time are still needed to provide a broader safety aspect for the vaccines currently under use for this population. 
medRxiv preprint doi: https://doi.org/10.1101/2021.12.14.21267777; this version posted December 17, 2021. The copyright holder for this preprint (which was not certified by peer review) is the author/funder, who has granted medRxiv a license to display the preprint in perpetuity.

It is made available under a CC-BY-ND 4.0 International license .

\section{Introduction}

38 The Coronavirus disease 2019 (COVID-19) has been shown to be less lethal than previous coronavirus 39 diseases, although it is highly contagious. Also, a higher risk of severe disease has been associated with aging and comorbidities. ${ }^{1}$ Equally important increased risk has been noted in pregnant and postpartum

41 women, making them particularly vulnerable to COVID-19. ${ }^{1}$ Studies have shown that, when compared to

42 non-pregnant, pregnant women might develop more severe symptoms, being at increased risk of

43 requiring hospitalization in intensive care unit, along with invasive ventilation, extra corporeal

44 membrane oxygenation and mortality. ${ }^{2,3}$ In Brazil, more than 18 thousand cases of severe acute

45 respiratory syndrome (SARS) by COVID-19 were recorded in pregnant and postpartum women, resulting

46 in almost 1,500 deaths by June $2021 .{ }^{4}$ Likewise, a $20 \%$ increase in maternal mortality rate was observed

47 in $2020 .^{4}$

48 Until now, there is still lack of evidence regarding safety and efficacy of the vaccines in pregnant and 49 postpartum women, since they were not in included in initial studies of COVID-19 vaccines. ${ }^{5}$ Even though, considering their higher susceptibility to COVID-19, vaccination for this group has been

51 conducted by assessing risks and benefits. ${ }^{6}$ COVID-19 immunization started on January 2021 in Brazil

52 and, in March 2021, pregnant and postpartum women with comorbidities were defined as priority

53 group. ${ }^{7}$ In April 2021, Ministry of Health (MoH) recommended that this subgroup should be vaccinated,

54 as long as a careful assessment was carried out with the physician, regardless of the gestational age. ${ }^{7}$

55 Due to adverse events experience by this subgroup, in May 2021 vaccination was changed again only for 56 those women with comorbidity, and, in July 2021, changed to include the entire maternal population. ${ }^{7}$

57 Four COVID-19 vaccines were initially recommended - Sinovac/Butantan, Janssen, AstraZeneca and

58 Pfizer/BioNTech, although after May 2021 there was a recommendation to remain only

59 Sinovac/Butantan and Pfizer/BioNTech vaccines for this group ${ }^{8,9}$ 
medRxiv preprint doi: https://doi.org/10.1101/2021.12.14.21267777; this version posted December 17, 2021. The copyright holder for this preprint (which was not certified by peer review) is the author/funder, who has granted medRxiv a license to display the preprint in perpetuity.

It is made available under a CC-BY-ND 4.0 International license .

60

61

62

63

64

65

66

67

68

69

70

71

72

73

74

75

77

78

79

80

81

82

83

84

By November 2021, about 1,7 million doses have been administered in this group, with an estimative to vaccinate more than 2,5 million pregnant and postpartum women in the country. ${ }^{8,10}$ Post authorization safety studies are a way to provide more evidence for this population. However, up to now, there are few evidence regarding the safety profile of those vaccines for pregnant and postpartum women from real world evidence perspective, considering pharmacovigilance systems as main source of information, especially for low and middle-income countries (LMIC), such as Brazil. ${ }^{11}$ In that way, this study aims to describe the incidence of adverse events $(\mathrm{AE})$ reported by pregnant and postpartum women after receiving vaccines approved for use in the early stage of vaccination campaign (April 2021 to August 2021) in Brazil.

\section{Methods}

\section{Surveillance Systems and Covered Population}

In Brazil, records of adverse events following immunization (AEFI) in vaccinated individuals in the public services are made available by the General Coordination of the National Immunization Program (NIP).

The NIP is responsible for the registration, investigation and causality analysis of AEFI reported by the public health system. ${ }^{12}$ For this study we requested the SI-EAPV (AEFI Surveillance Information System) dataset to the Brazilian MoH, using the Fala BR platform (https://www.gov.br/acessoainformacao/pt-

$\underline{\mathrm{br} / \mathrm{falabr}}) .{ }^{13}$ This system is linked to the national system for reporting AE related to the use of drugs and vaccines in VigiMed, adopted at the end of 2018 by Anvisa, as a result of its partnership with the Uppsala Monitoring Centre (UMC) ${ }^{14}$ The SI-EAPV has the purpose to systematically monitor the notifications, investigate and consolidate data relating to AEFI occurring at the National, State, Regional, Municipal and local levels, contributing to improve the safety in the use of immunizations, with a passive surveillance approach. Following the stablished flow, during the COVID-19 pandemic, all AEFI related to COVID-19 vaccines have been notified in SI-EAPV. ${ }^{15}$ To assess the total number of vaccines doses administered in the country, the National Vaccination Campaign against COVID-19 database 
medRxiv preprint doi: https://doi.org/10.1101/2021.12.14.21267777; this version posted December 17, 2021. The copyright holder for this preprint (which was not certified by peer review) is the author/funder, who has granted medRxiv a license to display the preprint in perpetuity.

It is made available under a CC-BY-ND 4.0 International license .

85 (“Campanha Nacional de Vacinação contra a COVID-19”), from OpenDatasus, were used. ${ }^{16}$ This dataset

86 is updated daily and, for this study, we used data from 3 November 2021. Pregnant women were

87 identified in the datasets as those who reported to be pregnant at the time they received the vaccine

88 and postpartum were considered those women who reported to be breastfeeding in the SI-EAPV and

89 who declared to be at postpartum at the moment of the vaccination.

90 Registries of AEFI with more than $50 \%$ of variables with missing data were excluded from the study.

91 Quality check procedures within the dataset were performed; this led to the exclusion of São Paulo

92 State from the analysis to minimize potential selection and information bias since the data was

93 underreported.

94 Study setting and outcomes

95

96 We analyzed AEFI notifications reported by pregnant and postpartum women who received any COVID-

9719 vaccine authorized and available in Brazil for use. AEFI could be reported as adverse event (AE) or

98 immunization error (IE), after receiving at least one dose of a COVID-19 vaccine, including: CoronaVac

99 (Sinovac/Butantan), Ad26.COV2.S (Janssen), ChAdOx1 nCoV-19 and BBV152 (AstraZeneca) and/ or

100 BNT162b2 (Pfizer/BioNTech).

101 Demographic characteristics were described according to the age, race/ethnicity, region of the country

102 where the notification was reported and the maternal situation of the woman. The AE were described

103 according to the type (local, systemic and maternal) ${ }^{17}$, severity (severe and non-severe) as well as the

104 case evolution (death, under investigation, cure without sequelae, unknown/ loss of follow-up and

105 under investigation). AE reported as "COVID-19", "PCR positive to COVID-19" and the like were classified

106 as inconclusive and those reported as "vaccination error", "inadvertent exposure to vaccine",

107 "contraindication" was classified as inconsistent. 
medRxiv preprint doi: https://doi.org/10.1101/2021.12.14.21267777; this version posted December 17, 2021. The copyright holder for this preprint (which was not certified by peer review) is the author/funder, who has granted medRxiv a license to display the preprint in perpetuity.

It is made available under a CC-BY-ND 4.0 International license .

108

109

110

111

112

113

114

115

116

117

118

119

120

121

122

123

124

125

126 127 (Supplementary material 1). and second dose.,

\section{Statistical Analysis}

\section{Results}

Additionally, considering that $\mathrm{MoH}$ changed the recommendation to vaccinate this groups only with vaccines that do not contain viral vector, the same woman could have received different vaccines as first

Description of AE notifications characteristics were performed for women reporting to be pregnant or at postpartum after receiving a COVID-19 vaccine from April to August 2021. AE were presented as number and frequency (\%) for the outcomes of interest. The incidence rate (IR) of AE per 100,000 doses applied was also estimated with $95 \%$ confidence interval $(\mathrm{CI})$. IR was calculated dividing the number of $\mathrm{AE}$ notified during the period of the study by the number of doses administered in the same group in the same period. Data analyses were conducted using Python version 3.6.5 (Python Software Foundation).

Datasets used were public and anonymized, protecting the confidentiality and privacy of all patients. ${ }^{18}$ All activities were conducted according to the applicable federal laws. ${ }^{19}$

From April to August 2021, a total of 3,333 AEFI reported by Brazilian pregnant and postpartum women who received COVID-19 vaccines in the SI-EAPV were included in the study. Of those, 473 were from women who received Sinovac/Butantan, 788 Pfizer/BioNTech, 2,016 AstraZeneca and 56 Janssen (Figure 1). AE was the most common reported AEFI by this population (74.59\%). Regarding IE, they were reported in $25.29 \%$ of the notifications, being more frequent among pregnant and postpartum women who received Sinovac/Butantan and Pfizer/BioNTech vaccines $(60.47 \%$ and $73.21 \%$, respectively)

129 AE notifications were more frequent among pregnant and postpartum women aged 20 to 35 years old, with a mean age of 28.56 (Standard Deviation 7.2), who reported as white (42.84\%) and brown (36.89\%) 
medRxiv preprint doi: https://doi.org/10.1101/2021.12.14.21267777; this version posted December 17, 2021. The copyright holder for this preprint (which was not certified by peer review) is the author/funder, who has granted medRxiv a license to display the preprint in perpetuity.

It is made available under a CC-BY-ND 4.0 International license .

131 (Table 1). From a regional perspective, even excluding the state of São Paulo, the South (34.31\%) and

132 Southeast (33.79\%) regions had most part of the notification from pregnant and postpartum women,

133 although it changed according to the vaccine received: for Sinovac/Butantan the highest were noted in

134 the South (40.64\%), for Pfizer/BioNTech in the Southeast (45.45\%), for AstraZeneca in the South

135 (35.75\%) and for Janssen in the Northeast (46.67\%). According to the maternal situation, few women

136 reported as being at postpartum (1.53\%) and the distribution within the three trimesters of pregnancy

137 were similar (25.34\% in the first, $30.01 \%$ in the second and $32.82 \%$ in the third trimester of pregnancy)

138 (Table 1).

Incidence of adverse events

140 The overall incidence of AE among pregnant and postpartum women was 309.4 / 100,000 doses of

141 vaccines administered $(95 \% \mathrm{Cl} 297.23,321.51)$. In the analysis according to the maternal situation, IR by

142 pregnant women was 404.3 / 100,000 doses $(95 \% \mathrm{Cl} 388.75,420.75)$ and by postpartum $19.6 / 100,000$

143 doses $(95 \% \mathrm{Cl} 13.47,25.78)$. Regarding the four vaccines available in the country, Sinovac/Butantan

144 vaccine had the lowest IR (74.08 / 100,000 doses; 95\% Cl 63.47, 84.69) (Table 2).

145 Stratifying the AE according to type, among pregnant women, systemic events were the most frequent

146 notified (82.03\%), followed by local (11.93\%) and maternal (4.78\%), being most of them classified as

147 non-severe (90.65\%) (Supplementary appendix 2). Also, the IR of systemic events in the Brazilian

148 pregnant women was the highest (249.88/ 100,000 doses: $95 \%$ Cl 238.97, 260.8). Maternal AE IR was

149 14.56/ 100,000 doses (95\% Cl 11.92, 17.2) (Table 3).

150 The most common maternal AE notified by pregnant and postpartum women included spontaneous

151 abortion (2.37\%) pregnancy bleeding (0.76\%) and neonatal death (0.52\%). Among the non-maternal AE,

152 headache (18.54\%), fever (13.79\%), myalgia (10.30\%) and pain (7.60\%) were the most reported. The 
medRxiv preprint doi: https://doi.org/10.1101/2021.12.14.21267777; this version posted December 17, 2021. The copyright holder for this preprint (which was not certified by peer review) is the author/funder, who has granted medRxiv a license to display the preprint in perpetuity.

It is made available under a CC-BY-ND 4.0 International license .

153 most frequent AE were similar among the four vaccines, except for pain, which was less frequent

154 reported for those who received Sinovac/Butantan vaccine (Table 4).

155 Regarding the case evolution of the events, $53.30 \%$ were missing and $30.85 \%$ reported as being cured

156 without sequelae (Supplementary material 3).

157 Discussion

158

159 In the COVID-19 pandemic reality, despite the recognition of the need for inclusion of pregnant and

160 postpartum women in clinical trials, the speed at which the COVID-19 vaccines were developed, and

161 trials conducted precluded inclusion of them. ${ }^{20}$ In that sense, post authorization safety studies are a way

162 to provide more evidence for this population.

163 Using surveillance data, we found more than 3,000 events notifications by pregnant and postpartum

164 women after receiving at least one dose of a COVID-19 vaccine in the early stage of the campaign in

165 Brazil. AE were the most common, although for some vaccines IE were more frequent - which may

166 reflect the changes in recommendation to vaccinate this group disposed by the Brazilian $\mathrm{MoH}^{8,21}$

167 Concerning the frequency of $\mathrm{AE}$, the distribution according to the age and race/ethnicity was similar

168 within all vaccines available. However, in a regional perspective, it differed as each region/state could

169 have differences in the cold chain distribution strategies. ${ }^{8}$ Among the maternal population, pregnant

170 women were responsible for most of the notifications reported in the period.

171 The overall incidence of AE found for this population was $309.4 / 100,000$ doses. Although there is a lack

172 of evidence regarding the safety of these vaccines in the maternal population, our findings are in

173 accordance with the available literature for other studies that assessed safety of COVID-19 in different

174 populations groups. An epidemiological bulletin from the Brazilian $\mathrm{MoH}$ from January to February of 
medRxiv preprint doi: https://doi.org/10.1101/2021.12.14.21267777; this version posted December 17, 2021. The copyright holder for this preprint (which was not certified by peer review) is the author/funder, who has granted medRxiv a license to display the preprint in perpetuity.

It is made available under a CC-BY-ND 4.0 International license .

1752021 showed a 350.9 AEFI notifications/ 100,000 doses of vaccines early administered in the Brazilian

176 population. ${ }^{22}$ Another study conducted in Minas Gerais state that assessed safety of COVID-19 vaccines

177 from January to March 2021 found an incidence rate of 777.12 AEFI per 100,000 doses applied, with

$17897 \%$ of them classified as non-severe $A E .^{23}$

179 In relation to the magnitude of our findings when compared to other vaccines recommended to

180 pregnant and postpartum women in Brazil, a study from Silveira IO et al, assessing adverse events from

181 the SI-EAPV database from 2015 to 2019 in Minas Gerais state, found an overall incidence of 76.9 AEFI

182 notifications/100,000 doses. ${ }^{24}$ Findings related to race/ ethnicity, type of event and case evolution were

183 also similar to the patterns found in our results. ${ }^{24}$

184 As for the systemic events found in our study, the most frequent types follow a similar pattern described

185 by Gattás VL, et al in relation to the ones found for influenza vaccine, which is recommended for any

186 gestational age in Brazil, as COVID-19 vaccines are. ${ }^{25}$ Although we have not compared pregnant to non-

187 pregnant women, there are studies suggesting that the physiologic changes in pregnancy seems to not

188 materially affect non-maternal events. ${ }^{26,27}$

Additionally, our study describes with more emphasis systemic events classified as maternal, showing an

190 incidence of 14.56 AE notifications/ 100,000 doses, of which spontaneous abortion was the most

191 frequent type of event (2.37\%) and with differences in the frequency found for the different types of

192 vaccines available. Brazilian data up to 2019 showed a proportion of $3.4 \%$ of spontaneous abortion in

193 the country. Meanwhile, spontaneous abortion incidence in the literature varies from $6.5 \%$ to $21 \%$ of

194 pregnancies, and it is recognized as one of the most common complications during a pregnancy. ${ }^{28-30}$ In

195 addition, a study assessing safety of mRNA COVID-19 vaccines in pregnant population in the United

196 States assessed by the V-Safe pregnancy registry system found an overall frequency of spontaneous

197 abortion of $12.6 \%$ among pregnant women who received a COVID-19 vaccines. ${ }^{26}$ Cardoso BB et al ${ }^{31}$, 
medRxiv preprint doi: https://doi.org/10.1101/2021.12.14.21267777; this version posted December 17, 2021. The copyright holder for this preprint (which was not certified by peer review) is the author/funder, who has granted medRxiv a license to display the preprint in perpetuity.

It is made available under a CC-BY-ND 4.0 International license .

198 however, argues that data on abortion and its complications may be incomplete in Brazil, since the

199 hospitalizations occurred due to an abortion is only one data source to estimate the total number of

200 abortions in the country. ${ }^{31}$

201 When comparing the different vaccines administered in this population in Brazil, we found that

202 Sinovac/Butantan and Pfizer/BioNTech vaccines had the lowest IR of AE, which is in line with $\mathrm{MoH}$

203 recommendations to only administer them in pregnant and postpartum woman. ${ }^{8,32}$

204 Our study has some limitations. The AEFI notifications used in this study are subject to limitations of

205 passive surveillance system. This means that each health level routinely and periodically sends

206 information about the events subject to surveillance at the immediately superior. In the same way, the

207 classifications in the database might be susceptible to the interpretation of the person filling out the

208 system, implying in the possibility of lack of uniformity in reporting the characteristics of the event and

209 in the place where the information is filled in the form of the surveillance system. Although these

210 systems generate valuable information regarding the description of the occurrence of adverse events,

211 they usually do not allow establishing causality between the occurrence of AEFI and the vaccine..$^{11,33-35}$ In

212 that sense, our study is unable to evaluate AE outcomes that might occur in association with exposures

213 earlier in pregnancy or postpartum period.

214 Furthermore, the definition of postpartum women varied in the data sources used - which may

215 underestimate the incidence in this population. In the same direction, the Brazilian obstetric

216 observatory for COVID-19 has been showing that there are inconsistencies in the vaccination

217 information fulfilling, since they found pregnant and postpartum women of male sex, and AEFI notified

218 for COVID-19 vaccines administered previous to the vaccination campaign start and over 55 years old. ${ }^{4}$ 
medRxiv preprint doi: https://doi.org/10.1101/2021.12.14.21267777; this version posted December 17, 2021. The copyright holder for this preprint (which was not certified by peer review) is the author/funder, who has granted medRxiv a license to display the preprint in perpetuity.

It is made available under a CC-BY-ND 4.0 International license .

219

220

221

222

223

224

225

226

227

228

229

230

231

232

233

234

235

236

237

238

Another potential limitation of our analyses is the underreporting of AE. SIEAPV is a passive surveillance system. Underreporting can occur due to difficulties in the conclusion of cases investigations and in adherence of the population to notify the events. In that sense, mild to moderate events might be more underreported than severe that required hospitalization or more intensive care. On the other hand, each of the four vaccines were available in different moments (Sinovac/Butantan and AstraZeneca since January, Pfizer/BioNTech since May and Janssen since July 2021). ${ }^{8}$ The Janssen vaccine was first provided to the population when there was already the recommendation not to vaccinate pregnant and postpartum women with viral vector vaccines, which led to a small number of doses administered in this population, hence, a low number of notifications up to the cut-off period of this study. In the same sense, Sinovac/Butantan and AstraZeneca vaccines were available in the beginning of the campaign, when only women with comorbidities were being vaccinated. ${ }^{8}$ Also, some of the AE presented in this study might be still under investigation during the study period and might not have a final classification.

Nevertheless, our study allows a better understand of COVID-19 vaccines safety profile under a vaccination campaign placed during a pandemic setting in a LMIC as Brazil. We found a similar pattern of

$A E$ as stated in other studies, with even better results for non-viral vector vaccines, corroborating that vaccination of this groups should continue as a priority. Further studies appraising a longer time for a better understanding adverse events incidence in relation to second and booster doses and the component of vaccine interchangeability are still needed to provide a broader safety aspect for the vaccines currently under use for this population. 
medRxiv preprint doi: https://doi.org/10.1101/2021.12.14.21267777; this version posted December 17, 2021. The copyright holder for this preprint (which was not certified by peer review) is the author/funder, who has granted medRxiv a license to display the preprint in perpetuity. It is made available under a CC-BY-ND 4.0 International license .

\section{Contributors}

240 AJLA, YPQ and GSJ conceptualized the study. RGP, RVF, AJLA and CZD analyzed the data. RGP and RVF

241 curated the data. AJLA, YPQ, CZD and GSJ wrote the first draft of the manuscript. YPQ, XM, WDY and

242 other authors reviewed and edited revisions of the manuscript, had full access to all the data in the

243 study, and had final responsibility for the decision to submit for publication.

\section{Declaration of interests}

245 RGP, RVF, AJLA, GSI and CZD are employees of IQVIA Brazil which was contracted by Sinovac Life 246 Sciences to conduct the study.

247 YPQ, XM, WDY are employees of Sinovac Life Sciences.

248

249 Acknowledgments 
medRxiv preprint doi: https://doi.org/10.1101/2021.12.14.21267777; this version posted December 17, 2021. The copyright holder for this preprint (which was not certified by peer review) is the author/funder, who has granted medRxiv a license to display the preprint in perpetuity.

It is made available under a CC-BY-ND 4.0 International license .

251

References

252 1. Bchetnia M, Girard C, Duchaine C, Laprise C. Journal of Infection and Public Health The outbreak

253 of the novel severe acute respiratory syndrome coronavirus 2 ( SARS-CoV-2): A review of the

254 current global status. J Infect Public Health [Internet] 2020;13(11):1601-10. Available from:

$255 \quad$ https://doi.org/10.1016/j.jiph.2020.07.011

2562 Roggero P, Prefumo F, Silva M, et al. Maternal and Neonatal Morbidity and Mortality Among

257 Pregnant Women With and Without COVID-19 Infection The INTERCOVID Multinational Cohort

258 Study. 2021;1-10.

259 3. Rasmussen SA, Kelley CF, Jamieson DJ, Horton JP. Coronavirus Disease 2019 ( COVID-19)

260 Vaccines and Pregnancy What Obstetricians Need to Know. 2021;137(3):408-14.

2614 Rodrigues A, Lacerda L, Francisco R. Brazilian Obstetric Observatory. arXiv Prepr

$262 \quad$ 2021;arXiv:2105:1-19.

2635 5eath PT, Doare K Le, Khalil A. Inclusion of pregnant women in COVID-19 vaccine development.

264 Lancet Infect Dis [Internet] 2020;20(9):1007-8. Available from: http://dx.doi.org/10.1016/S1473-

$265 \quad 3099(20) 30638-1$

266 6. Quintana SM. We have Vaccine for COVID-19! What to Recommend for Pregnant Women? Rev

267 Bras Ginecol e Obs 2021;43(2):81-3.

268 7. Brasil. Ministério da Saúde. NOTA TÉCNICA N² / 2021-SECOVID / GAB / SECOVID / MS. 2021.

269 8. Brasil. Ministério da Saúde. Secretaria Extraordinária de Enfrentamento à COVID-19. PLANO

270 NACIONAL DE OPERACIONALIZAÇÃO DA VACINAÇÃO CONTRA A COVID-19. 11ª . Brasília/DF: 2021.

271 9. Brasil. Ministério da Saúde. Secretaria de Vigilância em Saúde. Departamento de Imunizações e 
medRxiv preprint doi: https://doi.org/10.1101/2021.12.14.21267777; this version posted December 17, 2021. The copyright holder for this preprint (which was not certified by peer review) is the author/funder, who has granted medRxiv a license to display the preprint in perpetuity.

It is made available under a CC-BY-ND 4.0 International license .

Doenças Transmissíveis. Nota técnica n 651/2021-cgpni/deidt/svs/ms 1. 2021;4-7.

273 10. Rodrigues NB, Mclntyre RS, Lipsitz O, et al. A simplified 6-Item clinician administered dissociative symptom scale (CADSS-6) for monitoring dissociative effects of sub-anesthetic ketamine infusions. J Affect Disord 2021;282:160-4.

11. Development P. Maternal Immunization Safety Monitoring in Low- and Middle-Income Countries[?: A Roadmap for Program Development Building an approach that is practical ,.

12. Moura ADA, Rouberte ESC, Lima FET, Chaves CS, Canto SVE, Lima GG de. Sistema de Informação de Eventos Adversos Pós-Vacinação (SI-EAPV): vantagens e desafios / Post-Vaccination Adverse Event Information System (SI-EAPV): advantages and challenges. Brazilian J Heal Rev

13. Fala.BR - Plataforma Integrada de Ouvidoria e Acesso à Informação [Internet]. Available from: https://www.gov.br/acessoainformacao/pt-br/falabr

14. BRASIL. ANVISA. BOLETIM DE FARMACOVIGILÂNCIA N ${ }^{\circ} 11$ [Internet]. 2020. Available from: https://www.gov.br/anvisa/pt-br/centraisdeconteudo/publicacoes/fiscalizacao-emonitoramento/farmacovigilancia/boletins-de-farmacovigilancia/boletim-de-farmacovigilanciano-11.pdf/view

15. BRASIL. Ministério da Saúde. SISTEMA DE INFORMAÇÕES DO PROGRAMA NACIONAL DE IMUNIZAÇÕES EVENTOS ADVERSOS PÓS-VACINAÇÃO: Manual do usuario. 2003.

16. Brasil. Ministério da Saúde. Campanha Nacional de Vacinação contra Covid-19 [Internet]. [cited 2021 Aug 5];Available from: https://opendatasus.saude.gov.br/fr/dataset/covid-19-vacinacao

17. World Health Organization (WHO). Generic protocol A prospective cohort study investigating maternal , pregnancy and neonatal outcomes for women and neonates infected with SARS-CoV- 
medRxiv preprint doi: https://doi.org/10.1101/2021.12.14.21267777; this version posted December 17, 2021. The copyright holder for this preprint (which was not certified by peer review) is the author/funder, who has granted medRxiv a license to display the preprint in perpetuity.

It is made available under a CC-BY-ND 4.0 International license .

2. 2020;(December).

295 18. Brasil. Presidência da República. Lei Geral de Proteção de Dados Pessoais (LGPD). Brasil: 2018.

296 19. Brasil. Conselho Nacional de Saúde. RESOLUÇÃO N 510, DE 07 DE ABRIL DE 2016 O. 2016.

297 20. Craig AM, Hughes BL, Swamy GK. Expert Review Coronavirus disease 2019 vaccines in pregnancy. Am J Obstet Gynecol MFM [Internet] 2021;3(2):100295. Available from:

https://doi.org/10.1016/j.ajogmf.2020.100295

21. Brasil. Ministério da saúde. secretaria de Vigilância em saúde. Boletim epidemiológico especial.

Doença pelo Novo Coronavírus - COVID-19 [Internet]. 2021. Available from:

302

https://www.gov.br/saude/pt-

303

br/media/pdf/2021/novembro/26/boletim_epidemiologico_covid_90_26nov21_eapv3b.pdf

304 22. Brasil. Ministério da Saúde. Secretaria de Vigilância em Saúde. Situação epidemiológica dos eventos adversos pós-vacinação contra a covid-19, Brasil, 2021. 2021;52.

23. Silva RB da, Silva TPR da, Sato APS, et al. Adverse events following immunization against SARSCoV-2 ( covid-19) in the state of Minas Gerais. 2021;2:1-10.

24. Oliveira PMN de, Lignani LK, Conceição DA da, et al. O panorama da vigilância de eventos adversos pós-vacinação ao fim da década de 2010]?: importância , ferramentas e desafios Surveillance of adverse events following immunization in the late 2010s?: an overview of the importance, tools, and challenges El. 2020;

312 25. Gattás VL, Braga PE, Koike ME, et al. Safety assessment of seasonal trivalent influenza vaccine produced by Instituto Butantan from 2013 to 2017. J São Paulo Inst Trop Med 2018;(November 2018):1-8. 
medRxiv preprint doi: https://doi.org/10.1101/2021.12.14.21267777; this version posted December 17, 2021. The copyright holder for this preprint (which was not certified by peer review) is the author/funder, who has granted medRxiv a license to display the preprint in perpetuity.

It is made available under a CC-BY-ND 4.0 International license .

315 26. Shimabukuro TT, Kim SY, Myers TR, et al. Preliminary Findings of mRNA Covid-19 Vaccine Safety

316 in Pregnant Persons. N Engl J Med 2021;384(24).

317 27. Riley LE. Edi t or i a I s mRNA Covid-19 Vaccines in Pregnant Women. 2021;2342-3.

318 28. Rodini ESO, Tsuribe PM, Maria L, Moreira V, Oliveira M De, Capannacci J. Abortamentos

319 espontâneos?]: estudos citogenéticos e riscos de recorrência Spontaneous abortions[?

320 cytogenetic studies and risks of occurrence. 2004;11(1):50-2.

321 29. Zheng D, Li C, Wu T, Tang K. Factors associated with spontaneous abortion: a cross-sectional

322 study of Chinese populations. Reprod Health [Internet] 2017;14(1):33. Available from:

323 http://reproductive-health-journal.biomedcentral.com/articles/10.1186/s12978-017-0297-2

324 30. Fergusson DM, John Horwood L, Ridder EM. Abortion in young women and subsequent mental

325 health. J Child Psychol Psychiatry [Internet] 2006;47(1):16-24. Available from:

326 https://onlinelibrary.wiley.com/doi/10.1111/j.1469-7610.2005.01538.x

327 31. Cardoso BB, Saraceni V. Abortion in Brazil: what do the official data say? 2020;1-13.

328 32. Brasil. Ministério da Saúde. Manual de vigilância epidemiológica de eventos adversos pós-

329 vacinação. Brasília: 2021.

330 33. Silveira IO da, Silva TPR da, Oliveira BM, et al. Adverse events following immunization in pregnant 331 women from Minas Gerais. 2021;1-10.

332 34. Brasil. ANVISA. Plano de Monitoramento de Eventos Adversos de Medicamentos e Vacinas Pós-

333 Autorização de Uso Emergencial[?]: Diretrizes e Estratégias de Farmacovigilância para o

334 enfrentamento da COVID-19. 2021.

335 35. Pacheco F, Domingues C, Maranhão A, et al. Análise do Sistema de Informação da Vigilância de 
medRxiv preprint doi: https://doi.org/10.1101/2021.12.14.21267777; this version posted December 17, 2021. The copyright holder for this preprint (which was not certified by peer review) is the author/funder, who has granted medRxiv a license to display the preprint in perpetuity. It is made available under a CC-BY-ND 4.0 International license. 
Table 1. Sociodemographic characteristics of pregnant and postpartum women that notified adverse events after receiving vaccines against

3 COVID-19

\begin{tabular}{|c|c|c|c|c|c|c|c|c|c|c|}
\hline & \multicolumn{2}{|c|}{ Sinovac/Butantan } & \multicolumn{2}{|c|}{ Pfizer/BioNTech } & \multicolumn{2}{|c|}{ AstraZeneca' } & \multicolumn{2}{|c|}{ Janssen } & \multicolumn{2}{|c|}{ Total } \\
\hline & $\begin{array}{c}\text { AE } \\
(n=187)\end{array}$ & $\%$ & $\begin{array}{c}A E \\
(n=572)\end{array}$ & $\%$ & $\begin{array}{c}A E \\
(n=1712)\end{array}$ & $\%$ & $\begin{array}{c}A E \\
(n=15)\end{array}$ & $\%$ & $\begin{array}{c}A E \\
(n=2,486)\end{array}$ & $\%$ \\
\hline \multicolumn{11}{|c|}{ Age group (years old) } \\
\hline$<15$ & 0 & $0.0 \%$ & 6 & $1.05 \%$ & 5 & $0.29 \%$ & 0 & $0.0 \%$ & 11,00 & $0.44 \%$ \\
\hline 16 to 20 & 18 & $9.63 \%$ & 76 & $13.29 \%$ & 180 & $10.51 \%$ & 2 & $13.33 \%$ & 276,00 & $11.1 \%$ \\
\hline 21 to 25 & 47 & $25.13 \%$ & 127 & $22.2 \%$ & 460 & $26.87 \%$ & 7 & $46.67 \%$ & 641,00 & $25.78 \%$ \\
\hline 26 to 30 & 47 & $25.13 \%$ & 101 & $17.66 \%$ & 438 & $25.58 \%$ & 3 & $20.0 \%$ & 589,00 & $23.69 \%$ \\
\hline 31 to 35 & 51 & $27.27 \%$ & 159 & $27.8 \%$ & 398 & $23.25 \%$ & 0 & $0.0 \%$ & 608,00 & $24.46 \%$ \\
\hline 36 to 40 & 15 & $8.02 \%$ & 68 & $11.89 \%$ & 184 & $10.75 \%$ & 0 & $0.0 \%$ & 267,00 & $10.74 \%$ \\
\hline 41 to 45 & 8 & $4.28 \%$ & 29 & $5.07 \%$ & 20 & $1.17 \%$ & 3 & $20.0 \%$ & 60,00 & $2.41 \%$ \\
\hline 46 to 50 & 1 & $0.53 \%$ & 1 & $0.17 \%$ & 0 & $0.0 \%$ & 0 & $0.0 \%$ & 2,00 & $0.08 \%$ \\
\hline$>50$ & 0 & $0.0 \%$ & 5 & $0.87 \%$ & 26 & $1.52 \%$ & 0 & $0.0 \%$ & 31,00 & $1.25 \%$ \\
\hline Inconsistent $^{2}$ & 0 & $0.0 \%$ & 0 & $0.0 \%$ & 1 & $0.06 \%$ & 0 & $0.0 \%$ & 1,00 & $0.04 \%$ \\
\hline
\end{tabular}


Race/ethnicity

\begin{tabular}{|c|c|c|c|c|c|c|c|c|c|c|}
\hline White & 70 & $37.43 \%$ & 222 & $38.81 \%$ & 770 & $44.98 \%$ & 3 & $20.0 \%$ & 1065 & $42.84 \%$ \\
\hline Black & 12 & $6.42 \%$ & 46 & $8.04 \%$ & 80 & $4.67 \%$ & 0 & - & 138 & $5.55 \%$ \\
\hline Yellow & 1 & $0.53 \%$ & 2 & $0.35 \%$ & 7 & $0.41 \%$ & 0 & - & 10 & $0.4 \%$ \\
\hline Brown & 79 & $42.25 \%$ & 220 & $38.46 \%$ & 608 & $35.51 \%$ & 10 & $66.67 \%$ & 917 & $36.89 \%$ \\
\hline Indigenous & 1 & $0.53 \%$ & 0 & - & 1 & $0.06 \%$ & 0 & - & 2 & $0.08 \%$ \\
\hline Ignored & 24 & $12.83 \%$ & 82 & $14.34 \%$ & 246 & $14.37 \%$ & 2 & $13.33 \%$ & 354 & $14.24 \%$ \\
\hline \multicolumn{11}{|c|}{ Region of notification } \\
\hline South & 76 & $40.64 \%$ & 162 & $28.32 \%$ & 612 & $35.75 \%$ & 3 & $20.0 \%$ & 853 & $34.31 \%$ \\
\hline Southeast & 53 & $28.34 \%$ & 260 & $45.45 \%$ & 524 & $30.61 \%$ & 3 & $20.0 \%$ & 840 & $33.79 \%$ \\
\hline North & 14 & $7.49 \%$ & 32 & $5.59 \%$ & 70 & $4.09 \%$ & 0 & - & 116 & $4.67 \%$ \\
\hline Northeast & 21 & $11.23 \%$ & 90 & $15.73 \%$ & 347 & $20.27 \%$ & 7 & $46.67 \%$ & 465 & $18.7 \%$ \\
\hline Midwest & 23 & $12.3 \%$ & 28 & $4.9 \%$ & 159 & $9.29 \%$ & 2 & $13.33 \%$ & 212 & $8.53 \%$ \\
\hline \multicolumn{11}{|c|}{ Maternal situation } \\
\hline 1st trimester & 76 & $40.64 \%$ & 173 & $30.24 \%$ & 368 & $21.5 \%$ & 13 & $86.67 \%$ & 630 & $25.34 \%$ \\
\hline 2nd trimester & 43 & $22.99 \%$ & 144 & $25.17 \%$ & 557 & $32.54 \%$ & 2 & $13.33 \%$ & 746 & $30.01 \%$ \\
\hline 3 rs trimester & 45 & $24.06 \%$ & 163 & $28.5 \%$ & 608 & $35.51 \%$ & 0 & - & 816 & $32.82 \%$ \\
\hline Postpartum & 8 & $4.28 \%$ & 12 & $2.1 \%$ & 18 & $1.05 \%$ & 0 & - & 38 & $1.53 \%$ \\
\hline Inconsistent ${ }^{3}$ & 10 & $5.35 \%$ & 72 & $12.59 \%$ & 136 & 7.94\% & 0 & - & 218 & $8.77 \%$ \\
\hline
\end{tabular}


Ignored ${ }^{4}$

5

$2.67 \%$

$1.4 \%$

25

$1.46 \%$

0

38

$1.53 \%$

4

AE: Adverse Event; ${ }^{1}$ AstraZeneca includes the vaccines ChAdOx1 nCoV-19 and BBV152; ${ }^{2}$ Ages unlikely to conceive a pregnancy were considered as inconsistent;

$5 \quad{ }^{3}$ Gestational ages inconsistent with a pregnancy i.e.: 12 months ${ }^{4}$ Stated as ignored in the notification.

* Due to lack of notifications in the State of São Paulo, the Southeast region will include the States of Rio de Janeiro, Espírito Santo and Minas Gerais;

8 Table 2. Incidence of adverse events notified by Brazilian pregnant and postpartum women by vaccine received

\begin{tabular}{|c|c|c|c|c|c|c|c|c|c|c|c|c|}
\hline & \multicolumn{4}{|c|}{ Overall } & \multicolumn{4}{|c|}{ Pregnant } & \multicolumn{4}{|c|}{ Postpartum } \\
\hline & \multicolumn{3}{|c|}{$\mathbf{N}$} & \multirow[b]{2}{*}{$95 \% \mathrm{Cl}$} & \multicolumn{3}{|c|}{$\mathbf{N}$} & \multicolumn{5}{|c|}{$\mathbf{N}$} \\
\hline & $\mathrm{AE}$ & doses & IR* & & $\mathbf{A E}$ & doses & IR* & $95 \% \mathrm{Cl}$ & $\mathrm{AE}$ & doses & $\mathbf{I R}^{*}$ & $95 \% \mathrm{Cl}$ \\
\hline Sinovac/Butantan & 187 & 252430 & 74.08 & $(63.47,84.69)$ & 179 & 193517 & 92.5 & $(78.95,106.04)$ & 9 & 58913 & 15.28 & $(5.3,25.26)$ \\
\hline Pfizer/BioNTech & 572 & 484310 & 118.11 & $(108.43,127.78)$ & 560 & 372980 & 150.14 & $(137.72,162.57)$ & 12 & 111330 & 10.78 & $(4.68,16.88$ 言 \\
\hline AstraZeneca ${ }^{1}$ & 1712 & 65435 & 2616.34 & $(2494.04,2738.64)$ & 1694 & 37954 & 4463.3 & $(4255.55,4671.04)$ & 18 & 27481 & 65.5 & $(35.25,95.7$ 䨖 \\
\hline Janssen & 15 & 1388 & 1080.69 & $(536.76,1624.62)$ & 15 & 367 & 4087.19 & $(2061.54,6112.85)$ & 0 & 1021 & 0 & $(0.0,0.0)$ \\
\hline Total & 2486 & 803563 & 309.37 & $(297.23,321.51)$ & 2448 & 604818 & 404.75 & $(388.75,420.75)$ & 39 & 198745 & 19.62 & $(13.47,25.78)$ \\
\hline
\end{tabular}

9 AE: Adverse Events; IR: incidence rate; $\mathrm{Cl}$ : Confidence interval;

10 * IR per 100,00 doses; ${ }^{1}$ AstraZeneca includes the vaccines ChAdOx1 nCoV-19 and BBV152;

11 N.B: Pregnant women can be breastfeeding; hence, they will count in pregnant and postpartum columns. 
Table 3. Incidence of AE among pregnant women according to the type and severity

\begin{tabular}{|c|c|c|c|c|c|c|c|c|c|c|}
\hline & \multicolumn{2}{|c|}{ Sinovac/Butantan } & \multicolumn{2}{|c|}{ Pfizer/BioNTech } & \multicolumn{2}{|c|}{ AstraZeneca $^{1}$} & \multicolumn{2}{|r|}{ Janssen } & \multicolumn{2}{|r|}{ Total } \\
\hline & IR* & $95 \% \mathrm{Cl}$ & IR* & $95 \% \mathrm{Cl}$ & IR* & $95 \% \mathrm{Cl}$ & $\mathbf{I R}^{*}$ & $95 \% \mathrm{Cl}$ & IR* & $95 \% \mathrm{Cl}$ \\
\hline Maternal & 10.3 & $(6.34,14.26)$ & 9.7 & $(6.93,12.48)$ & 65.71 & $(46.08,85.35)$ & 72.05 & $(0.0,213.2)$ & 14.56 & $(11.92,17.2)$ \\
\hline Systemic & 50.31 & $(41.56,59.06)$ & 89.41 & $(80.99,97.82)$ & 2194.5 & $(2082.29,2306.8)$ & 864.55 & $(377.51,1351.59)$ & 249.88 & $(238.97,260.8)$ \\
\hline Local & 4.36 & $(1.78,6.93)$ & 15.49 & $(11.98,18.99)$ & 311.76 & $(269.05,354.47)$ & 144.09 & $(0.0,343.65)$ & 36.34 & $(32.17,40.51)$ \\
\hline
\end{tabular}

13 IR: incidence rate; $\mathrm{Cl}$ : confidence interval; ${ }^{1}$ AstraZeneca includes the vaccines ChAdOx1 nCoV-19 and BBV152;

$14 \quad *$ IR per 100,000 doses administered.

15 Table 4. Frequency of most common adverse events experienced by pregnant and postpartum women receiving COVID-19 vaccines and who

16 reported an $\mathrm{AEFI}$

\begin{tabular}{|c|c|c|c|c|c|c|c|c|c|c|}
\hline & \multicolumn{2}{|c|}{ Sinovac/Butantan } & \multicolumn{2}{|c|}{ Pfizer/BioNTech } & \multicolumn{2}{|c|}{ AstraZeneca $^{1}$} & \multicolumn{2}{|c|}{ Janssen } & \multicolumn{2}{|c|}{ Total } \\
\hline & $\begin{array}{c}A E \\
(n=187)\end{array}$ & $\%$ & $\begin{array}{c}A E \\
(n=572)\end{array}$ & $\%$ & $\begin{array}{c}A E \\
(n=1712)\end{array}$ & $\%$ & $\begin{array}{c}A E \\
(n=15)\end{array}$ & $\%$ & $\begin{array}{c}A E \\
(n=2,486)\end{array}$ & $\%$ \\
\hline \multicolumn{11}{|l|}{ Maternal } \\
\hline Spontaneous abortion & 9 & $4.81 \%$ & 28 & $4.9 \%$ & 21 & $1.23 \%$ & 1 & $0.066 \%$ & 59 & $2.37 \%$ \\
\hline Pregnancy bleeding & 6 & $3.21 \%$ & 3 & $0.52 \%$ & 11 & $0.64 \%$ & 0 & $0 \%$ & 20 & $0.80 \%$ \\
\hline Neonatal death & 3 & $1.6 \%$ & 9 & $1.57 \%$ & 1 & $0.06 \%$ & 0 & $0 \%$ & 13 & $0.52 \%$ \\
\hline
\end{tabular}




\begin{tabular}{|c|c|c|c|c|c|c|c|c|c|c|}
\hline Premature birth & 1 & $0.53 \%$ & 3 & $0.52 \%$ & 3 & $0.18 \%$ & 0 & $0 \%$ & 7 & $0.28 \%$ \\
\hline Abdominal pregnancy & 3 & $1.6 \%$ & 0 & $0 \%$ & 0 & $0 \%$ & 0 & $0 \%$ & 3 & $0.12 \%$ \\
\hline \multicolumn{11}{|l|}{ Non-maternal } \\
\hline Headache & 20 & $10.7 \%$ & 77 & $13.46 \%$ & 360 & $21.03 \%$ & 4 & $28.57 \%$ & 461 & $18.54 \%$ \\
\hline Fever & 13 & $6.95 \%$ & 46 & $8.04 \%$ & 282 & $16.47 \%$ & 2 & $14.29 \%$ & 343 & $13.8 \%$ \\
\hline Myalgia & 12 & $6.42 \%$ & 37 & $6.47 \%$ & 206 & $12.03 \%$ & 1 & $7.14 \%$ & 256 & $10.3 \%$ \\
\hline Pain & 3 & $1.6 \%$ & 35 & $6.12 \%$ & 149 & $8.7 \%$ & 2 & $14.29 \%$ & 189 & $7.6 \%$ \\
\hline Vomit & 2 & $1.07 \%$ & 20 & $3.5 \%$ & 67 & $3.91 \%$ & 2 & $14.29 \%$ & 91 & $3.66 \%$ \\
\hline Chills & 4 & $2.14 \%$ & 8 & $1.4 \%$ & 77 & $4.5 \%$ & 0 & $0 \%$ & 89 & $3.58 \%$ \\
\hline Nausea & 2 & $1.07 \%$ & 19 & $3.32 \%$ & 62 & $3.62 \%$ & 1 & $7.14 \%$ & 84 & $3.38 \%$ \\
\hline Abdominal pain & 9 & $4.81 \%$ & 22 & $3.85 \%$ & 44 & $2.57 \%$ & 1 & $7.14 \%$ & 76 & $3.06 \%$ \\
\hline Diarrhea & 3 & $1.6 \%$ & 20 & $3.5 \%$ & 40 & $2.34 \%$ & 0 & $0 \%$ & 63 & $2.53 \%$ \\
\hline Arm Pain & 0 & $0 \%$ & 26 & $4.55 \%$ & 34 & $1.99 \%$ & 0 & $0 \%$ & 60 & $2.41 \%$ \\
\hline Asthenia & 6 & $3.21 \%$ & 15 & $2.62 \%$ & 35 & $2.04 \%$ & 0 & $0 \%$ & 56 & $2.25 \%$ \\
\hline Fatigue & 2 & $1.07 \%$ & 14 & $2.45 \%$ & 39 & $2.28 \%$ & 0 & $0 \%$ & 55 & $2.21 \%$ \\
\hline Cough & 7 & $3.74 \%$ & 28 & $4.9 \%$ & 17 & $0.99 \%$ & 0 & $0 \%$ & 52 & $2.09 \%$ \\
\hline Dyspnea & 5 & $2.67 \%$ & 15 & $2.62 \%$ & 31 & $1.81 \%$ & 0 & $0 \%$ & 51 & $2.05 \%$ \\
\hline Runny nose & 7 & $3.74 \%$ & 23 & $4.02 \%$ & 16 & $0.93 \%$ & 0 & $0 \%$ & 46 & $1.85 \%$ \\
\hline Sore throat & 4 & $2.14 \%$ & 11 & $1.92 \%$ & 22 & $1.29 \%$ & 0 & $0 \%$ & 37 & $1.49 \%$ \\
\hline
\end{tabular}


17 AE: Adverse event; ${ }^{1}$ AstraZeneca includes the vaccines ChAdOx1 nCoV-19 and BBV152. 
medRxiv preprint doi: https://doi.org/10.1101/2021.12.14.21267777; this version posted December 17, 2021. The copyright holder for this preprint (which was not certified by peer review) is the author/funder, who has granted medRxiv a license to display the preprint in perpetuity.

It is made available under a CC-BY-ND 4.0 International license .

\section{Figures}

2

\section{Figure 1. Attrition diagram}




\section{6,071}

AEFI notifications

Not eligible: 312,402
Total AEFI notifications in the dataset provided by the Ministry of Health $(\mathrm{MoH})$
Pregnant and postpartum women who received at least one dose of a COVID-19vaccine in Brazil

AEFI Notifications by pregnant and postpartum women
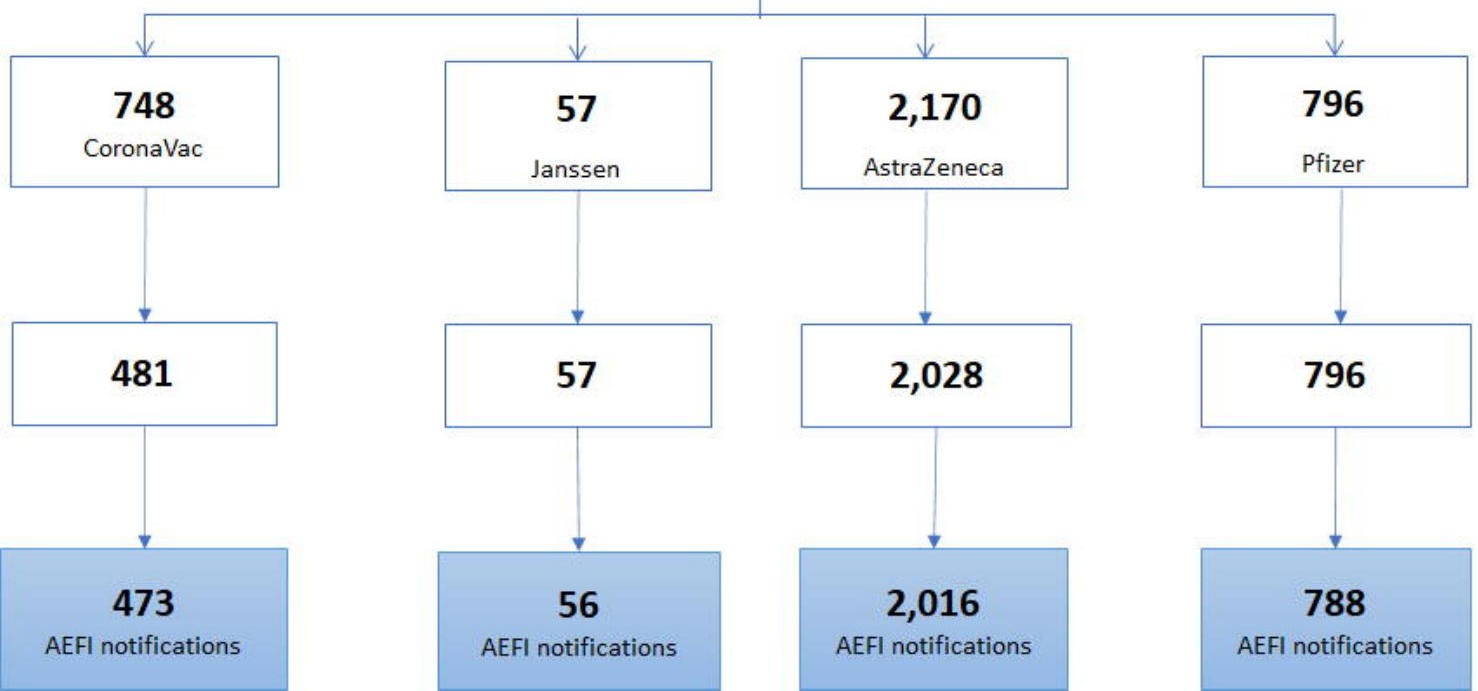

After $\mathrm{MoH}$ recommendation to vaccinate pregnant and postpartum women (with date between April and August of 2021) 